\begin{tabular}{|l|l|l||}
\hline \multicolumn{2}{|c|}{ PublisherInfo } \\
\hline \hline PublisherName & $:$ & BioMed Central \\
\hline \hline PublisherLocation & $:$ & London \\
\hline \hline PublisherImprintName & $:$ & BioMed Central \\
\hline \hline
\end{tabular}

\title{
Id-1, invasion and steroid response
}

\begin{tabular}{|l|l|l||}
\hline \multicolumn{2}{|c||}{ ArticleInfo } \\
\hline \hline ArticleID & $:$ & 3709 \\
\hline \hline ArticleDOI & $:$ & $10.1186 /$ bcr-2000-66672 \\
\hline \hline ArticleCitationID & $:$ & 66672 \\
\hline \hline ArticleSequenceNumber & $:$ & 75 \\
\hline \hline ArticleCategory & $:$ & Paper Report \\
\hline \hline ArticleFirstPage & $:$ & 1 \\
\hline \hline ArticleLastPage & $:$ & 4 \\
\hline \hline & & RegistrationDate : 2000-5-8 \\
ArticleHistory & $:$ & OnlineDate \\
\hline \hline ArticleCopyright & $:$ & Current Science Ltd2000-8 \\
\hline \hline ArticleGrants & $:$ & \\
\hline \hline ArticleContext & $:$ & 1305822 \\
\hline \hline
\end{tabular}


Aff1 Clatterbridge Cancer Research Trust, UK

\section{Keywords}

Differentiation, estradiol, growth, Id-1, invasion, progesterone, T47-D

\section{Introduction}

Id proteins are dominant-negative regulators of basic helix-loop-helix (bHLH) transcription factors. Id-1 has been shown to be an important mediator of mammary epithelial cell growth, differentiation and invasion. In a mouse mammary cell line (SCp2) constitutive expression of Id-1 inhibited differentiation, and stimulated both cell growth and invasiveness. Some highly aggressive, poorly differentiated, human cell lines expressed higher levels of Id-1 than those with less aggressive phenotypes.

\section{Aims}

To explore the possible link between human breast cancer progression and Id-1 expression, and to investigate the mechanism of Id-1 overexpression and the role of serum and steroid response.

\section{Comments}

This paper helps to establish Id-1 as a potentially important marker of aggressive breast cancer and starts to examine control of Id-1 expression by steroid action. The expression of Id- 1 influenced the behaviour of the cell lines studied, and is itself influenced by estradiol and progesterone. The work on breast tumour samples should be extended and the interaction with hormone receptor status explored.

\section{Methods}


Human cell lines were studied for serum response, Id-1 mRNA expression (northern blot) and Id-1 gene amplification (Southern blot). A luciferase reporter gene construct was used to map serum response elements in the Id-1 promoter $(-2.2 \mathrm{~kb}$ to $+1 \mathrm{bp})$. T47-D cells were transfected with a retroviral vector that resulted in constitutive Id-1 expression from a cytomegalovirus (CMV) promoter, as determined by western blot. These cells were analysed in growth assays (thymidine labelling) and invasion assays (Boyden chamber). Antisense and control oligonucleotides were used to monitor the effect of Id-1 down-regulation. Human tumour sections were used for immunohistochemical analysis.

\section{Results}

T47-D and MCF-7 cell lines (differentiated, non-invasive) expressed high levels of Id-1 mRNA when cultured in serum, but Id-1 mRNA was undetectable when cultured in serum-free medium for 2 days. MDA-MB-231 and MDA-MB-435 cells lines (poorly differentiated, highly aggressive) expressed Id-1 mRNA when cultured in media either with or without serum. This difference was not due to amplification of the Id-1 gene.Downregulation of reporter gene expression upon serum starvation closely followed mRNA downregulation (87\% in T47-D cf. 20\% in MDA-MB-231).Eight single cell clones of T47-D cells constitutively expressing Id-1 were isolated. Five clones were assessed for invasive activity, which was shown to be proportional to the level of Id-1 protein expression. A growth advantage was also noted in serum-free media. Very high expression of Id-1 was not seen, indicating possible toxicity. Estradiol (E2) and progesterone (Pg) have opposing effects on T47-D cells. E2 resulted in stimulation of Id-1 expression in serum-starved cells. The addition of Pg to E2-stimulated cells reduced Id-1 expression to control levels. Pg also reduced serum-stimulated Id-1 expression. Pg did not have the same inhibitory activity in MCF-7 cells lacking detectable levels of Pg receptors.Id-1 protein levels closely paralleled growth stimulation of T47-D cells and antisense Id-1 was able to block cell growth stimulated by E2. Constitutive expression of Id-1 blocked the inhibition of E2-stimulated cell growth by Pg.Eight of ten ductal carcinoma in situ(DCIS) samples were negative for Id-1 expression whereas seven of twelve infiltrating grade III ductal carcinomas were strongly positive.

\section{Discussion}

In contrast to T47-D and MCF-7, two cell lines with an aggressive phenotype had lost serumdependent Id-1 expression and exhibited constitutive expression. A large proportion of this differential regulation could be accounted for by Id-1 transcriptional control elements within a $2.2 \mathrm{~kb}$ promoter region.Constitutive, ectopic expression of Id-1 resulted in an increase of invasive activity and a growth advantage in growth factor deficient media. Id-1 was shown to be under control of E2 and Pg in T47-D cells, with Pg having a dominant effect over both E2 and serum growth factors. Id-1 expression would seem to mediate, at least in part, the growth stimulatory and inhibitory effects of E2 and Pg respectively. Transcriptional control is apparently important in the regulation of Id-1 expression.In a small sample of human breast tumours Id-1 protein was present more often in invasive carcinomas than in in situ lesions and may be a marker of aggressive behaviour. 


\section{References}

1. Lin CQ, Singh J, Murata K, Itahana Y, Parrinello S, Liang SH, Gillett CE, Campisi J, Desprez PY: A Role for Id-1 in the aggressive phenotype and steroid hormone response of human breast cancer cells.

Cancer Res. 2000, 60: 1332-1340. 